Iranian Quarterly Journal of Breast Disease. 2019; 12(3):17.

\section{Original Article \\ The Effect of Interval Training on the Expression of Tumor Suppressor Gene, Systemic Inflammation, and Tumor Volume in Breast Cancer-Bearing BALB/c Mice}

\author{
Sadeghipoor Vojdani $\mathbf{F}^{1}$, Agha-Alinejad $\mathbf{H}^{1^{*}}$, Molanouri Shamsi $\mathbf{M}^{1}$, Soudi \\ $\mathbf{S}^{2}$, Khanchi $\mathbf{S}^{1}$ \\ ${ }^{1}$ Physical Education \& Sport Sciences Department, Faculty of Humanities, Tarbiat \\ Modares University, Tehran, Iran \\ ${ }^{2}$ Immunology Department, Favulty of Medical Sciences, Tarbiat Modares University, \\ Tehran, Iran
}

Receive: $15 / 7 / 2019$ Accepted: 1/10/2019

*Corresponding Author: halinejad@modares.ac.ir

Ethics Approval: IR.MODARES.REC.1397.264

\begin{abstract}
Introduction: E-cadherin is expressed in most normal epithelial tissues. Loss of E-cadherin can cause dedifferentiation and invasiveness in human carcinomas, leading E-cadherin to be classified as a tumor suppressor. Therefore, the aim of this study was to investigate the effect of interval training on the expression of tumor suppressor gene E-cadherin in breast cancer-bearing $\mathrm{BALB} / \mathrm{c}$ mice.
\end{abstract}

Methods: Twenty female BALB/c mice were purchased from the Pasteur Institute and transferred to the Animal Laboratory of Tarbiat Modares University and randomly divided into four groups of training-cancer-rest, training-cancer-training, rest-cancer-rest, and rest-cancer-training. Cancer was induced by subcutaneous injection of 4T1 cell line. The mice performed an average-intensity interval training for 10 weeks, 5 days per week. Forty-eight hours after the last exercise session, the mice were sacrificed to measure the research variables. Gene expression was investigated using real-time PCR. The Kruskal-Wallis test was used to determine the statistical differences between groups.

Results: There was a significant difference in the E-cadherin gene expression between the training-cancer-training and rest-cancer-rest groups $(p=0.03)$. This difference was also observed between the training-cancertraining and training-cancer-rest groups $(\mathrm{p}=0.04)$.

Conclusion: Interval exercise training may influence the expression of major tumor suppressor genes and systemic inflammation involved in the development of metastasis and even reverse this process.

Keywords: E-Cadherin, High-intensity Interval Training, Breast Cancer, Metastasis 


\section{بررسى اثر تمرينات ورزشى تناوبى بر بيان ثن سركوبكر تومور، \\ التهاب سيستميك و حجم تومور در موشهاى مبتلا به سرطان يستان}

فرانى صادقى يور وجدانى'، حميد آقاعلىنزاد'"، مهديه ملانورى شمسى'، سارا صعودى'، سنا خانجى'

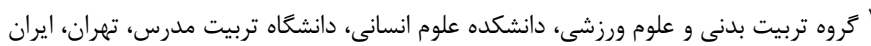

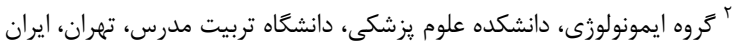

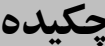

مقدمه: E-cadherin در بيشتر بافتهاى نرمال إييتليال بيان مىشود. از دست رفتن E-cadherin

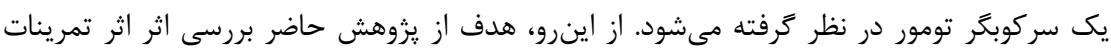

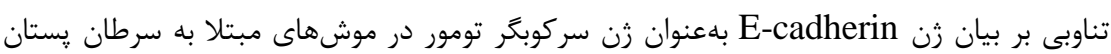

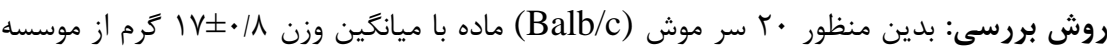

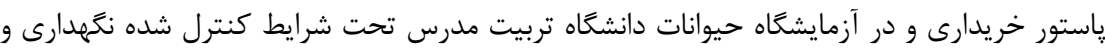

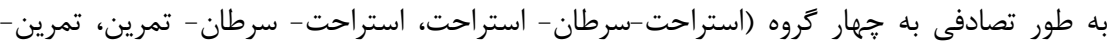

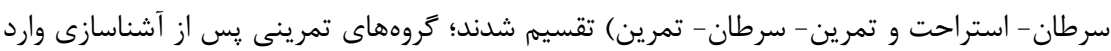

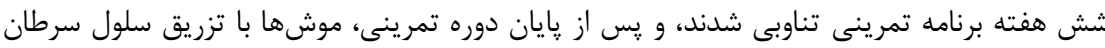

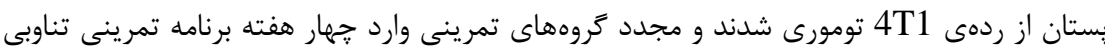

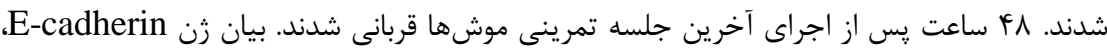

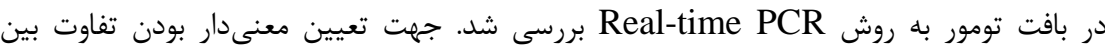
متغيرها از آزمون نايارامتريك كروسكال واليس استفاده كرديد. يافتهها: نتايج تفاوت معنادار زن E-cadherin را بين زروههاى تمرين- سرطان-تمرين و

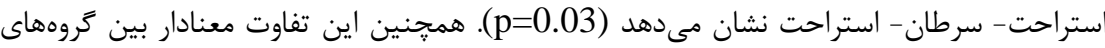

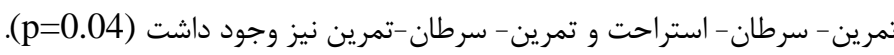
نتيجه

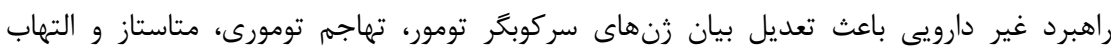

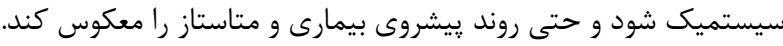
| وازههاى كليدى: E-cadherin، تمرين تناوبى، سرطان پِتان، متاستاز

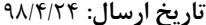

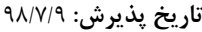

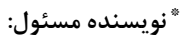
halinejad@modares.ac.ir 


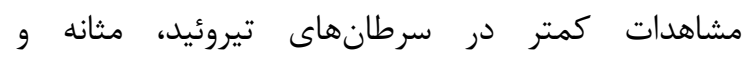
سرطانهاى مربوط به زنان، زن E-cadherin دجار موتاسيون شده و منجربه بيان يروتئينهاى غيرعملكردى زئن

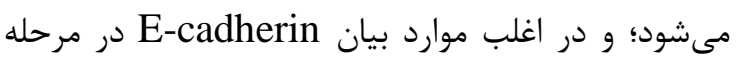
رونويسى تنظيم كاهشى مىيابد (^). از سوى ديكر سيستم ايمنى و رهايش مايوكاينها تحت تاثير تمرينات بدنى شدت متوسط قرار مى گيرد و تقويت مى گردد؛؛ كه

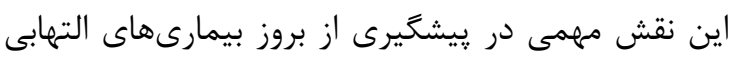

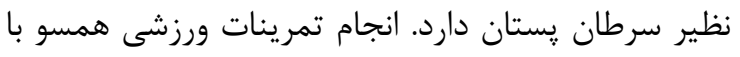
كاهش درصد جربى بدن و همجنين كاهش التهاب سيستميك درجه خفيف مىباشد كه در رياتوزنز سرطان نقش دارند. بهعلاوه فعاليت بدنى مى تواند باعث بيشخيرى

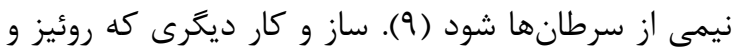

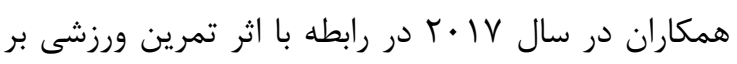

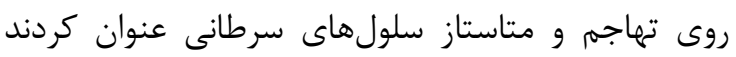
اين بود كه تمرين ورزشى مى تواند سطوح بتا-كاتنين و كامثن E-cadherin

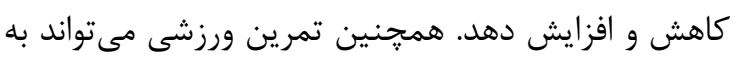

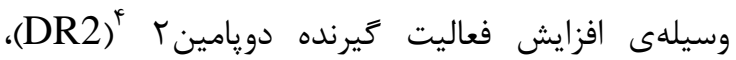

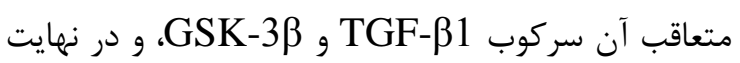

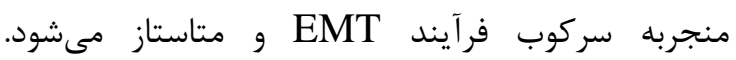

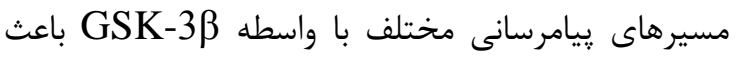

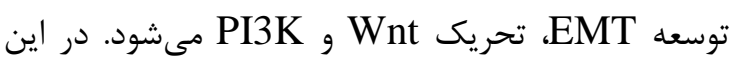
مسيرها، تنظيم افكتورهاى ديخر نظير بتا-كاتنين توسط ونائ

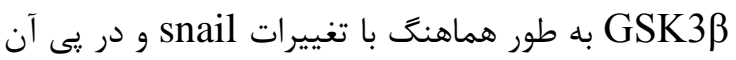
E-cadherin

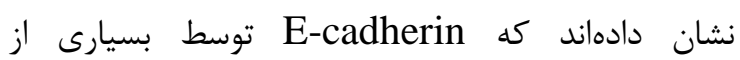

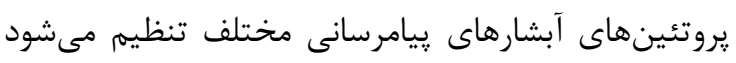

(1) (1)

تمرين ورزشى همجنين ممكن است با حفظ بيان

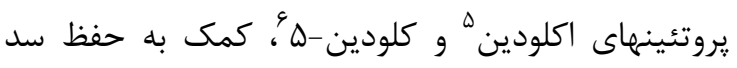

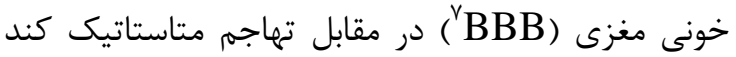

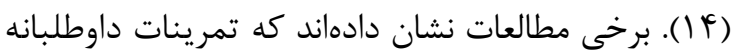
در موشهاى Apc Min/+ مبتلا به سرطان كلون به داديه ترتيب ميزان بتا-كاتنين و و كاهش و افزايش مىدهد (له ()). تمرينات اينتروال هم كه

\footnotetext{
${ }_{5}^{4}$ Dopamine Receptor2

5 occludin

${ }^{6}$ claudin-5

${ }^{7}$ Brain Blood Barrier
}

سرطان يكى از دلايل اصلى مرگ و مير در جهان است. در

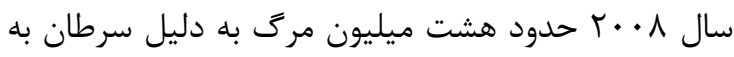

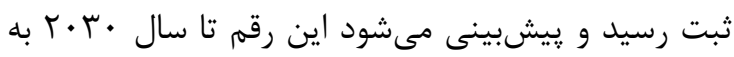
11 ميليون نفر برسد. سرطان يستان رايجترين سرطان در درد

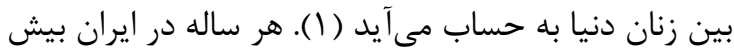

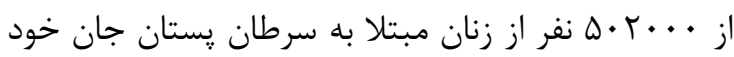

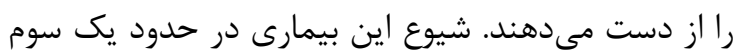
كل سرطان هاى زنان بوده است (r). براى سلولهاى سرطانى · •إن مشخصه عنوان شده است است.

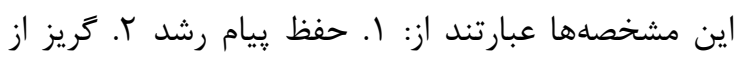

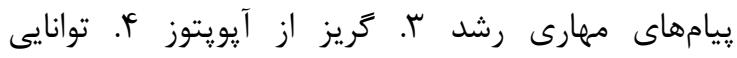

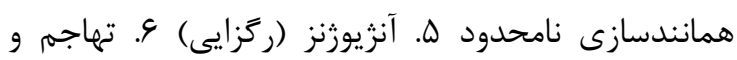

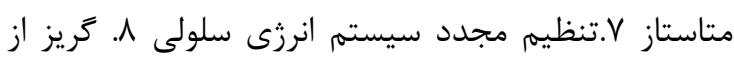

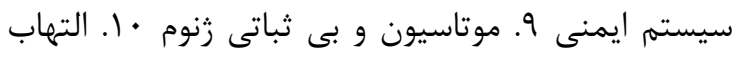

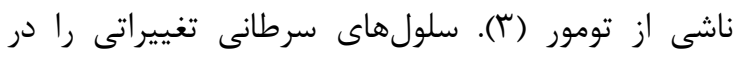

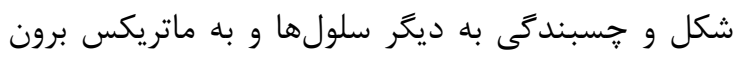

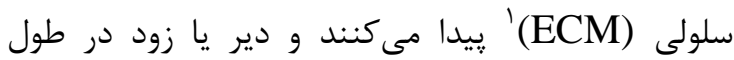

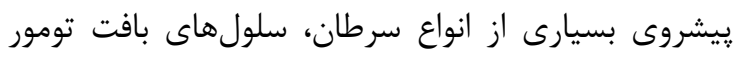

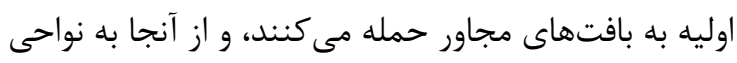

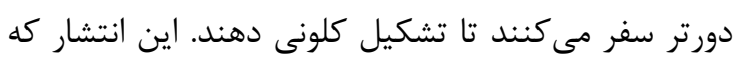

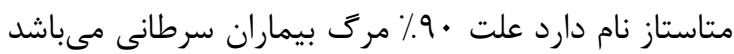

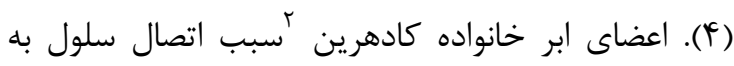

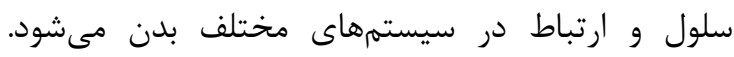
كادهرينها عوامل وابسته به كلسيم هستند كه به به عنوان

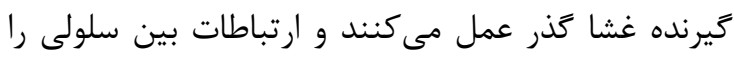
ميانجى

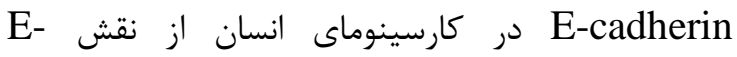
cadherin حمايت مى كند (ه، و). به عبارتى سلولهاى مهاجم

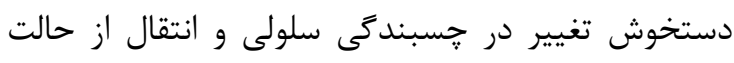

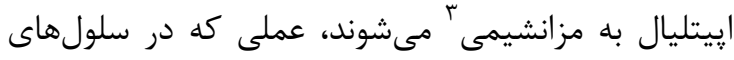

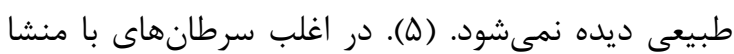

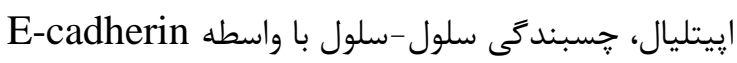

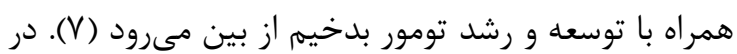

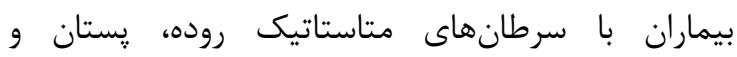

\footnotetext{
${ }^{1}$ Extracellular Matrix

${ }^{2}$ Cadherin

${ }^{3}$ Epithelial Mesenchymal Transition (EMT)
} 
كروه سوم (كروه استراحت- سرطان - تمرين) (STE) اين گروه تنها پِ از القاى تومور در برنامه تمرينى شركت

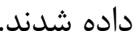
(STS) كروه جهارم (كروه استراحت- سرطان - استراحت)

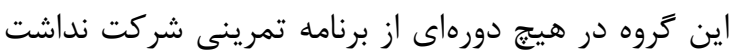
و تنها القاى سرطان بر روى آنها انجام كرفت.

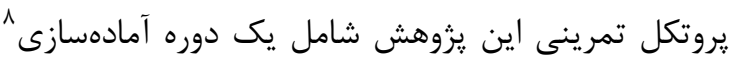

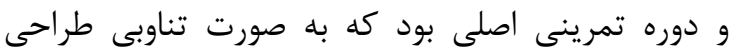

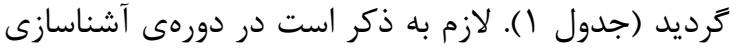

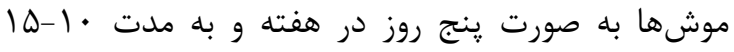
دقيقه با سرعت ^ متر در دقيقه بر روى نوار كردان رون راه

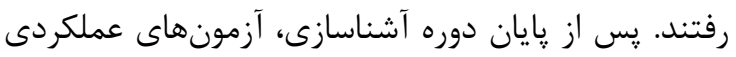

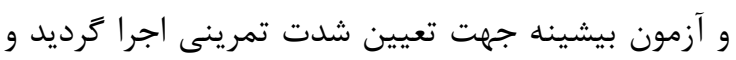

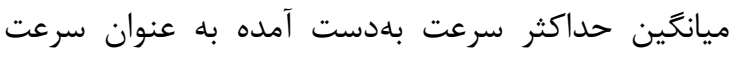

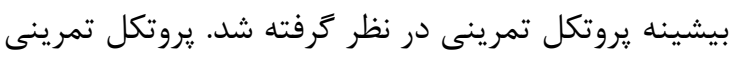
با •له و • V درصد سرعت بيشينه موشها (شدت متوسط) در · آ اينتروالهاى دو دقيقهاى اجرا شد.

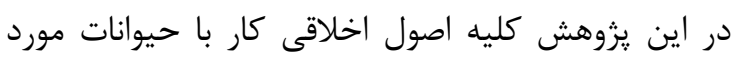
تأييد كميته اخلاق دانشخاه تربيت مدرس بر به إنه شماره تجقة تحقيق رعايت گرديد. لازم به ذكر است در اين آزمايش براى اجتناب از عوامل استرسزا، از شوك الكتريكى جهت

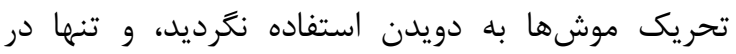

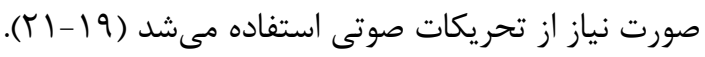
نحوه ايجاد تومور: جهت القاى سرطان متاستاتيك

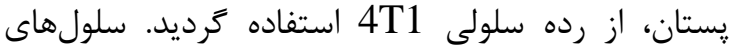

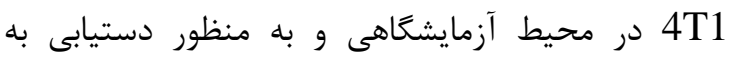

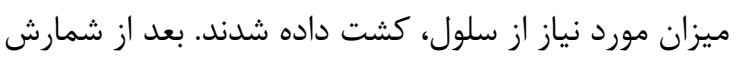
سلولى و اطمينان از رسيدن سلولها به تعداد مورد نياز،

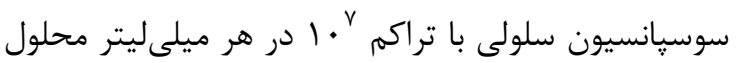

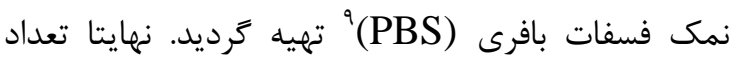

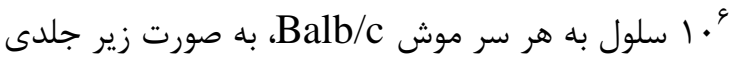
و به بالاى دست سمت راست موش تزريق گرديد.

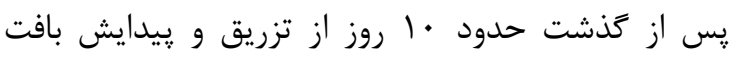
تومورى، هر هفته حجم تومور توسط كاليير ديجيتال مورد

\footnotetext{
${ }^{8}$ Preconditioning

${ }^{9}$ Phosphate buffered saline
}

شامل تمرينات كوتاه مدت، شدت بالا و با استراخت كوتاه و يا كم شدت است از علايمى مانند خستكى ڤا و تهوع جلوكيرى مى كنند (9). انجام تمرينات تناوبى همراه با

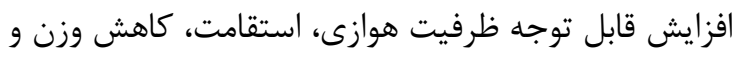
عملكرد متابوليك قلب براى افراد مبتلا به سرطان بوده است (IV). تاكنون يزوهشى در رابطه با اثر تمرينات

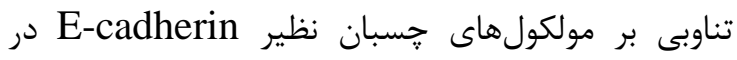
دست نمىباشد و بيشتر مطالعات در حوزه ورزش و وران سرطان اغلب به بررسى سيخنال هاى مرتبط با رشد تومور،

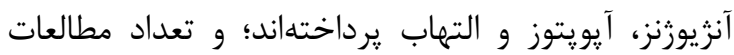
انجام شده در حيطه متاستاز و ورزش و به ويزه در بر بافت تومور سرطان קستان بسيار محدود است (N|). علاوه بر

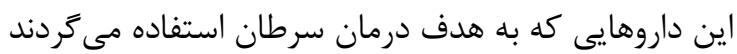

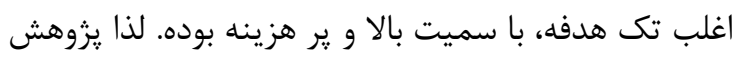

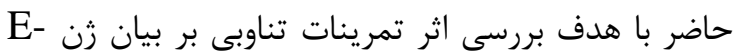

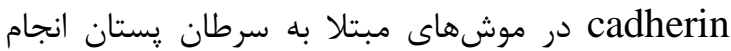

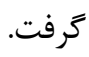

\section{مواد و روشها}

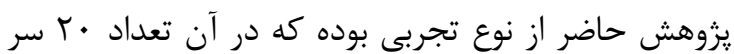

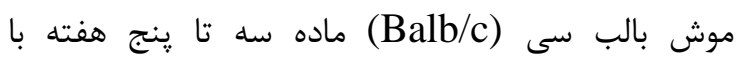

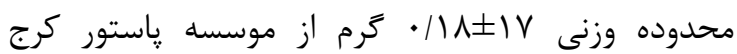
خريدارى و به آزمايشگاه حيوانات دانشگاه تربيت مدرس

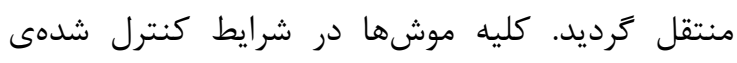

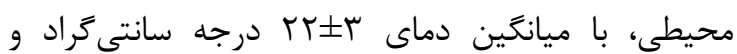

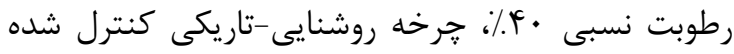

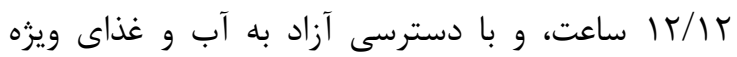

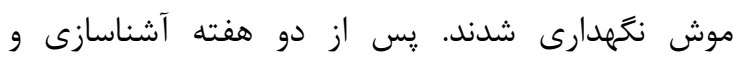
سازكارى حيوانات با محيط آزمايشعاه، موشها به شكل دارن تصادفى به جهار گروه پِنجتايى تقسيم شدند:

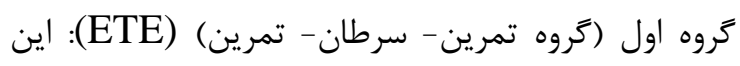
كَروه شامل ينج سر موش بالب-سى بود كه يس إن از اتمام دوره شش هفتهاى تمرين آماده سازى، با تزريق رده

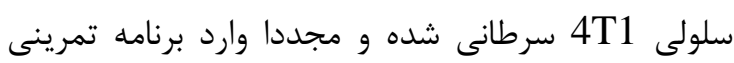
تناوبى شدند. كروه دوم (كروه تمرين- سرطان- استراحت) (ETS) اين

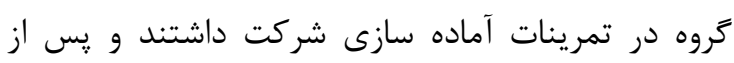
القاى تومور و ابتلا به سرطان وارد برنامه تمرينى نشدند. 


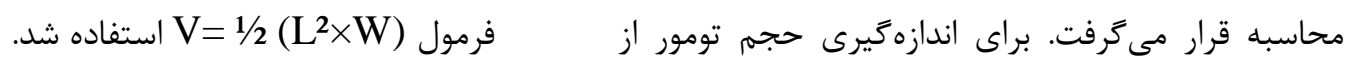

جدول ا: يروتكل تمرينى

\begin{tabular}{|c|c|c|c|c|}
\hline & دو هفته سوم & دو هفته دوم & دو هفته اول & $\begin{array}{c}\text { ييش از القاى تومور } \\
\text { Preconditioning }\end{array}$ \\
\hline & سرعت ه & سرعت: •r · & سرعت: ه| - r & \\
\hline & مدت: ·· اينتروال r & مدت: ·r اينتروال r & مدت: ·r اينتروال r & \\
\hline & دقيقهاى & دقيقهاى & دقيقهاى & \\
\hline هفته جهارم & هفته سوم & هفته دوم & هفته اول & يس از القاى تومور \\
\hline سرعت: • ·- |ه & سرعت: ه|--r & سرعت: & سرعت: D & \\
\hline مدت: ها اينتروال r & مدت: ها اينتروال r & مدت: ها اينتروال r & مدت: ها اينتروال r & \\
\hline دقيقهاى & دقيقهاى & دقيقهاى & دقيقهاى & \\
\hline
\end{tabular}

Applied Biosystems) فوروارد و ريورز زن E-cadherin و بتاكتين كه به عنوان

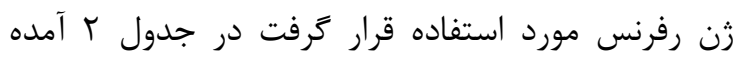

تجزيه و تحليل آمارى: به منظور بررسى نرمال بودن

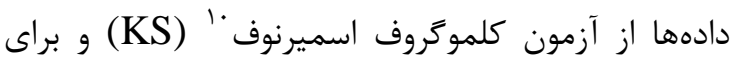

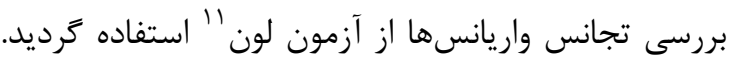

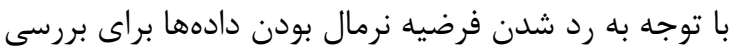

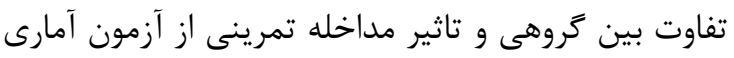

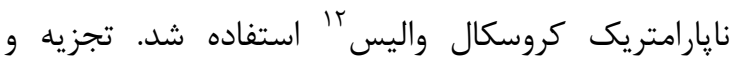

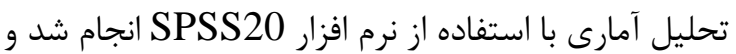
سطح معنادارى ه •/• در نظر كرفته شد.

\section{جدول r: توالى يرايمرها}

\begin{tabular}{lr}
\hline Gene Name & Sequence $\left(\mathbf{5}^{\prime} \boldsymbol{\rightarrow} \mathbf{3}\right.$ ') \\
\hline E-CadherinmusF & CTGCTGCTCCTACTGTTTCTACG \\
\hline E-CadherinmusR & TGGCTCAAATCAAAGTCCTGGTC \\
ACTBmusF & GGCTGTATTCCCCTCCATCG \\
\hline ACTBmusR & CCAGTTGGTAACAATGCCATGT \\
\hline
\end{tabular}

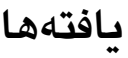

كزارش متغيرهاى بررسى شده در اين يزوهش در ذيل به

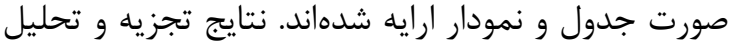

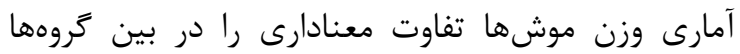

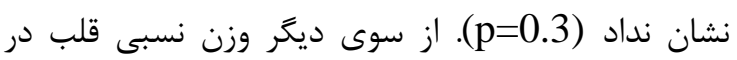
كروه STS كه در برنامه تمرينى شركت نداشتند از

\footnotetext{
${ }^{10}$ Kolmogorov smirnov

${ }^{11}$ Leven

${ }^{12}$ kruskal wallis
}

بر اين اساس حجم تومور در دو بعد اندازهگيرى شد؛ بدين

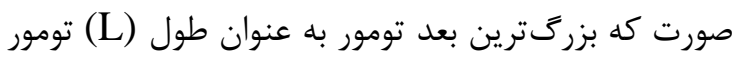

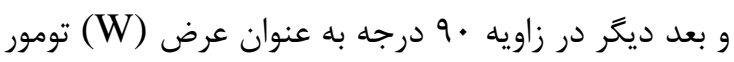
در نظر گرفته شد (Tr). استخراج و نكَهدارى بافت: FF ساعت پس از آخرين

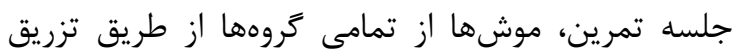

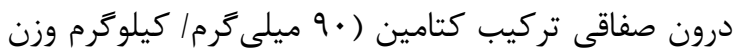

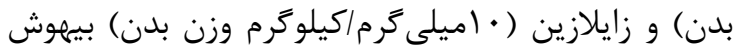

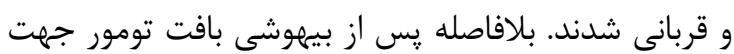

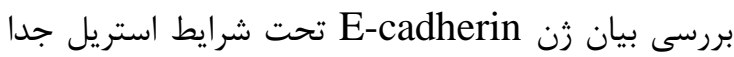
كرديد و سيس در نيتروزن مايع منجمد شد. بافت طحال، كبد و قلب براى بررسى غيرمستقيم التهاب سيستميك و ونائ

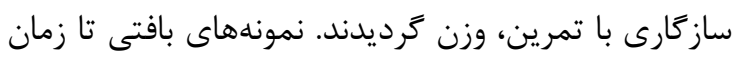

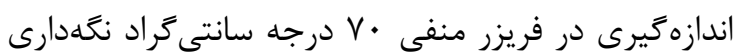

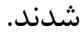
سنجش بيان زن: براى استخراج total RNA بافت

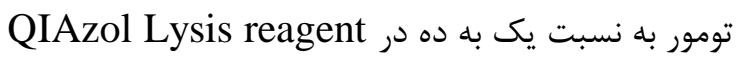
هموزن كرديد. و يروتكل طبق دستور شركت كيازن اجرا كرديد. اينتخريتى RNA توسط الكتروفورز با استفاده از

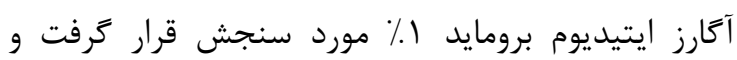

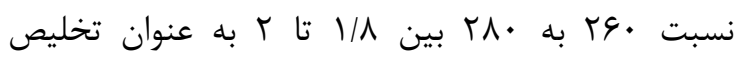
مطلوب تعريف كرديد. سنتز cDNA با استفاده از

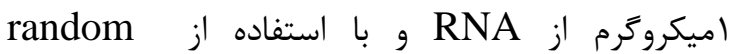
hexamer prime Reverse

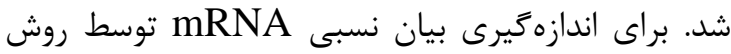
(AB stepone plus real-time PCR 
از سوى ديگر تجزيه و تحليل آمارى بيان زن E- Eان cadherin

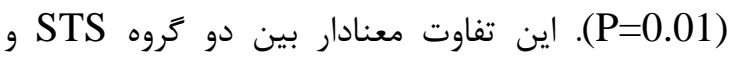
(p=0.04) ETS و همجنين ETE (p=0.03) ETE

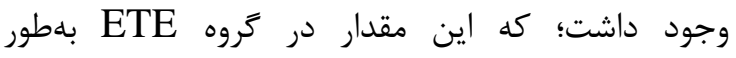
معنادارى بالاتر مىباشد (نمودار (). همجنين نتايج تجزيه

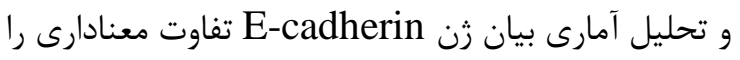
در بين گروهها نشان داد (P=0.01) واليس تفاوت معنادار بين دو كروه STS و

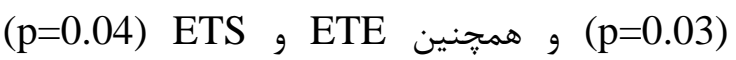

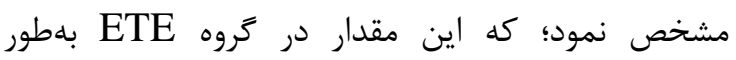
معنادارى بالاتر مىباشد (نمودار (1).
ديكر گروهها كمتر بود اما اين اختلاف از لحاظ آمارى معنى دار نبود (P=0.15). به منظور سنجش غيرمستقيم

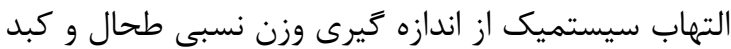

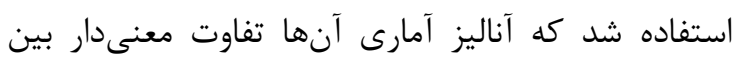

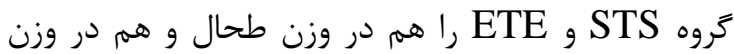
كبد نشان مىدهد؛ به علاوه در مورد وزن كبد تفات تفاو

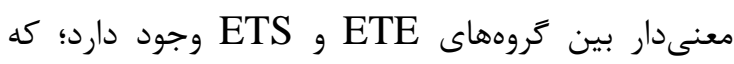
نشان از التهاب سيستميك در كروه

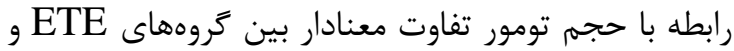

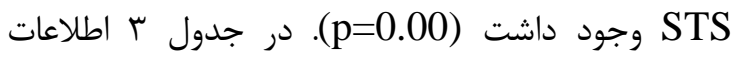
مربوطه به اين متغيرها ارايه شده است. علايم موجود در

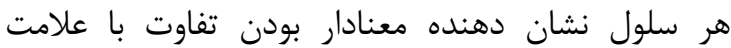
يكسان در همان رديف است.

\begin{tabular}{|c|c|c|c|c|c|}
\hline سطح معنىدارى & ETE & ETS & STE & STS & متغير / كروهها \\
\hline$\cdot / f$ & $r I / I V \pm I / r F$ & $r \mid / \cdot \Delta \pm \cdot / \Delta F$ & $r / / \Delta r \pm 1 / / r$ & $19 / 4 \pm r / 94$ & وزن بدن (كرم) \\
\hline$\cdot 110$ & $\Delta / \cdot 9 \pm \cdot / / \mathrm{V}$ & $c / Q 1 \pm \cdot / \cdot r$ & $\varphi / \cdot \pm \wedge \varepsilon / T \vee$ & $F / \cdot \pm r r / F F$ & وزن نسبى قلب (ميلى گرم/گرم) \\
\hline$\cdot 1 \cdot \cdot \wedge$ & f/99 & $\Delta / \| \pm \cdot / T F$ & $r / A V \pm \cdot / / r$ & $\Delta / 9 T \pm \cdot / 9$. & وزن نسبى طحال (ميلى گرم/ارم) \\
\hline$\cdot / \cdot \mathrm{f}^{\mathrm{f}}$ & 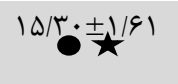 & $\stackrel{Q \Delta / V \wedge \pm \Delta / G .}{\star}$ & $\Delta Q / \cdot r \pm T / R Q$ & $98 / 19 \pm 11 / 99$ & وزن نسبى كبد (ميلى گرم/گرم) \\
\hline$\cdot / \cdot$ & $V / \Delta T \pm 1 / \cdot T$ & $F \Delta / V \Psi \pm 1 \Delta / q F$ & $19 / / Y \pm 1 Y / 1 \Lambda$ & 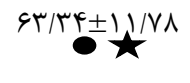 & ور (ميلى متر مكعب) \\
\hline
\end{tabular}

علايم موجود در هر سلول نشاندهندهى معنادار بودن تفاوت، با علامت يكسان در همان رديف است

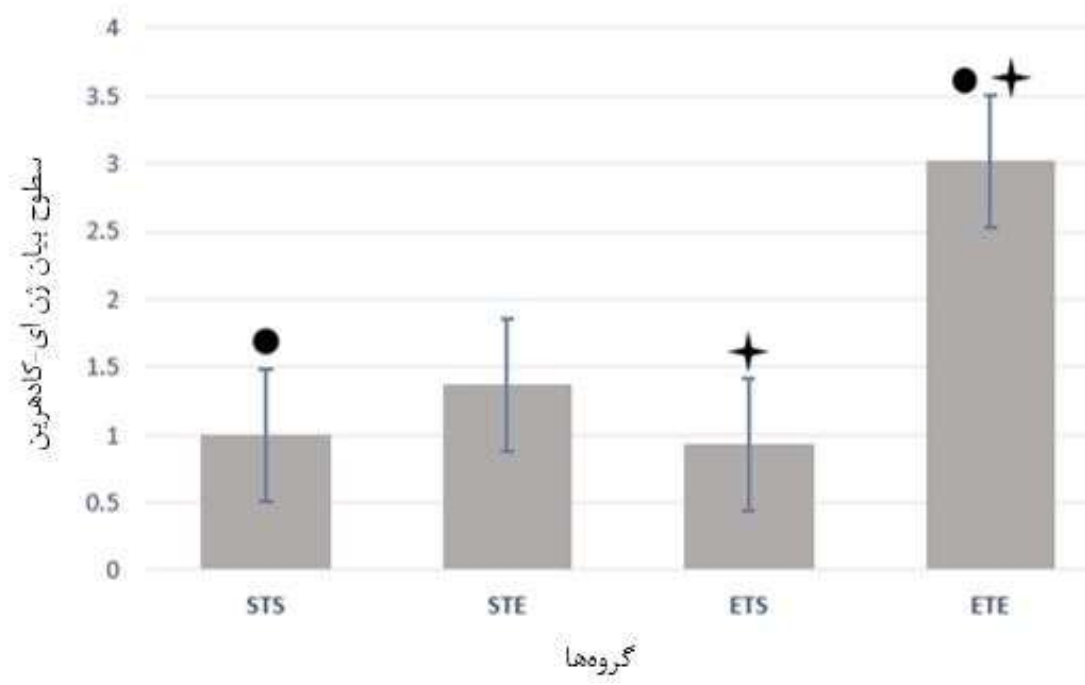

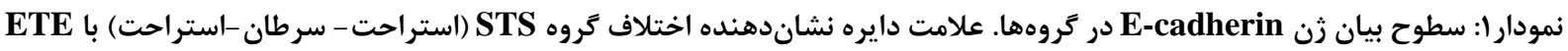

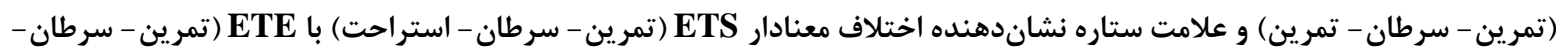


E-cadherin از جمله بيوماركرهايى است كه TGF- $\beta$

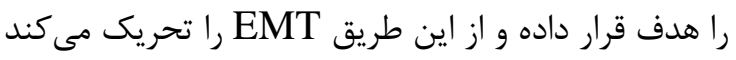

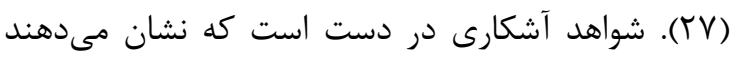

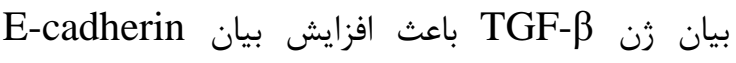

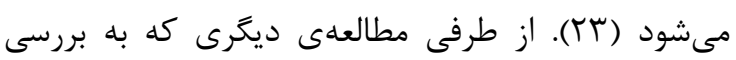
تاثيرات تمرينات ورزشى بر مGFمى دهد تمرينات تناوبى و تمرينات هوازى مى تورانند بيان

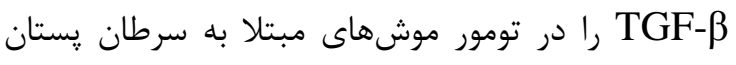

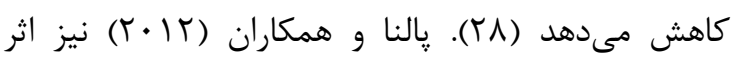
كاهنده تمرين ورزشى را بر بيان زن مان

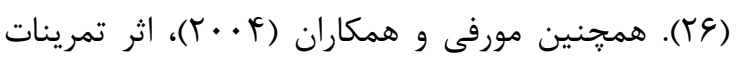

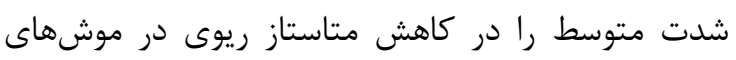

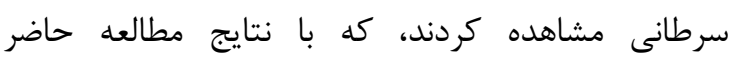

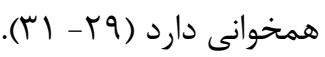

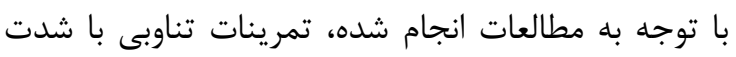

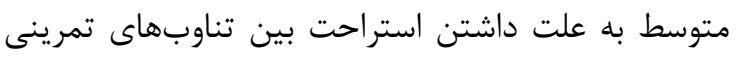

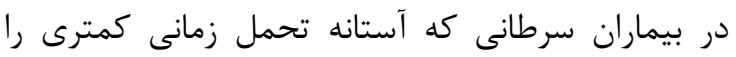

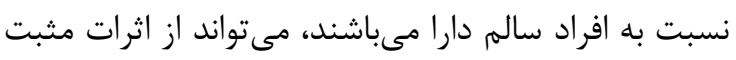

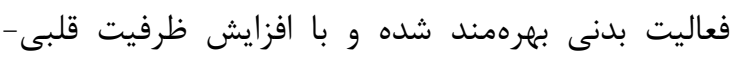

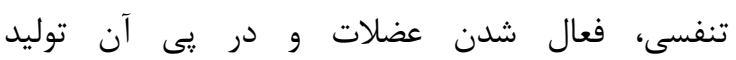

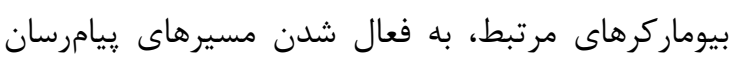

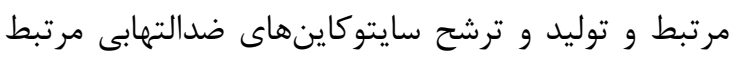

كردند.

همجنين نتايج يزوهش حاضر نشان داد كه رشد حجم

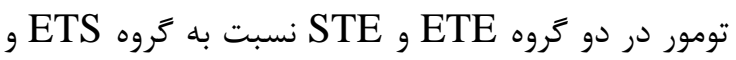

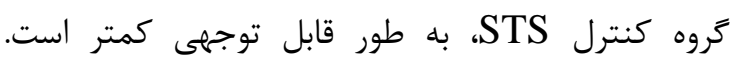

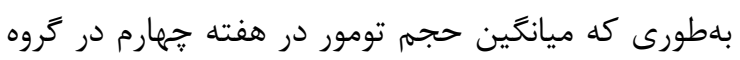
STS (p<0.05)

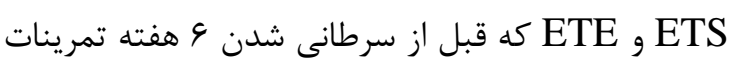

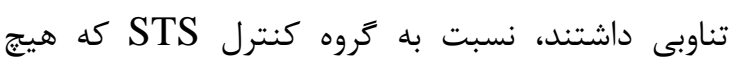

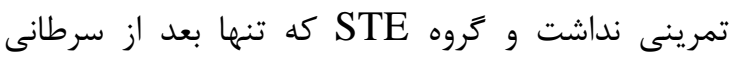

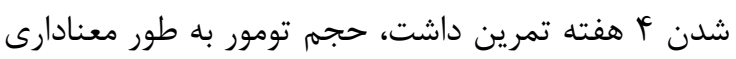
كمتر بود (p (p)

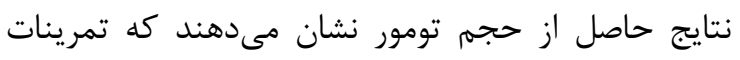

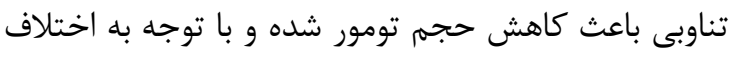

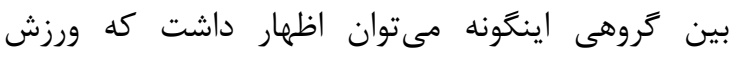

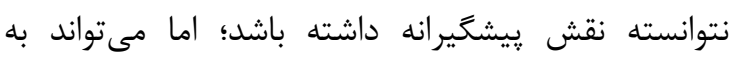

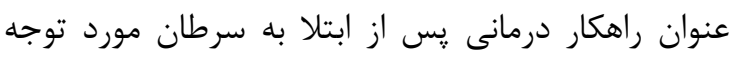

در مطالعه يِش رو به بررسى اثر تمرينات تناوبى بر بيان

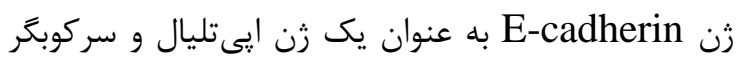

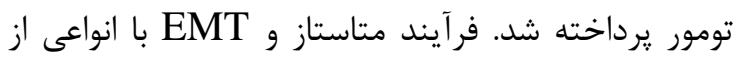
مسيرهاى קيامرسانى نظير Wnt/ $\beta$-catenin TNF- $\alpha$ و IL-8

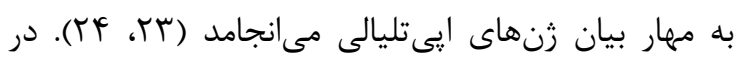

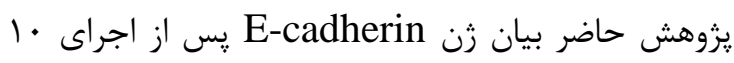
هفته تمرين تناوبى در كروه ETE

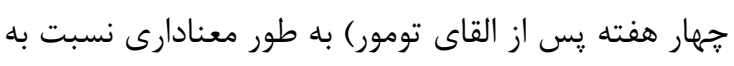

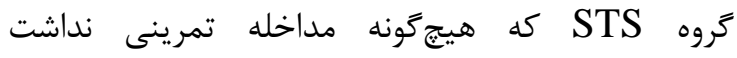
و عروه ETS (p=0.03)

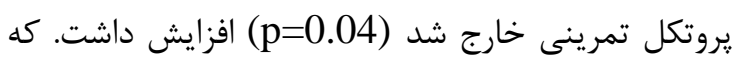

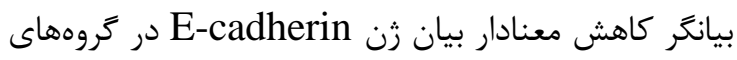

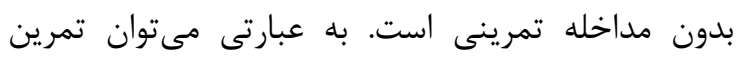

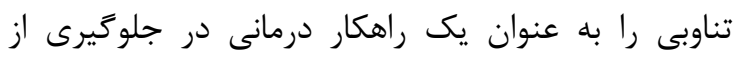

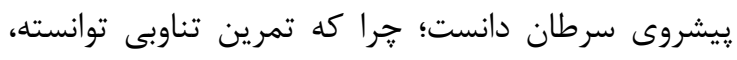

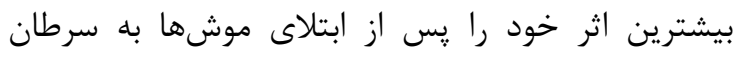

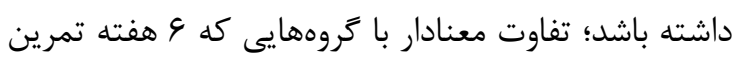

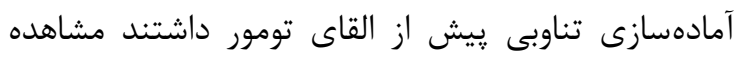
نشده است. تاكنون يزوهشى در زمينه تاثير تمرين تناوبى بر بيان زن E-cadherin

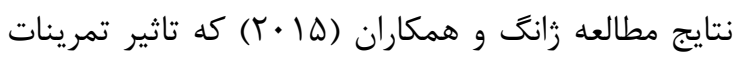
تداومى را بر بيان اين زن بررسى كردند، همخوانى دارئ دارد.

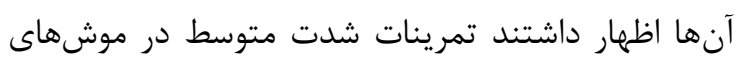

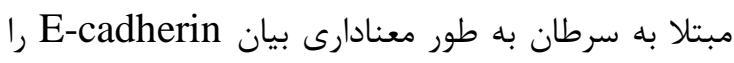

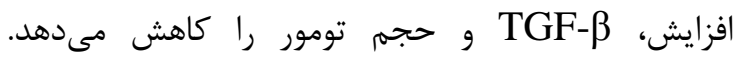
درحالى كه تمرينات شدت بالا يا مدت بالا تاثيرى همراه با باديا نتايج معكوس دارد (په).

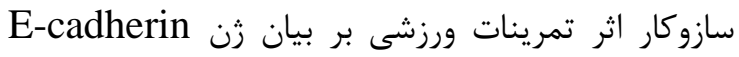

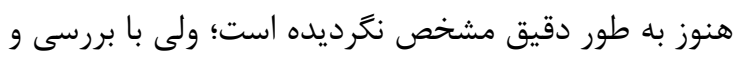

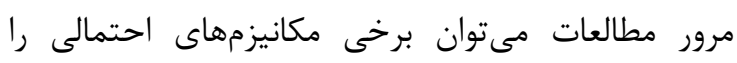
برشمرد. در تعدادى از مطالعات نقش سايتوكاينها به مانه

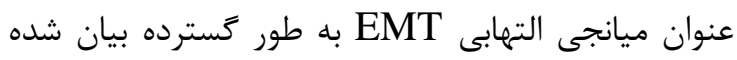

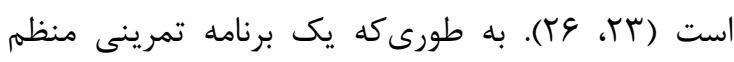

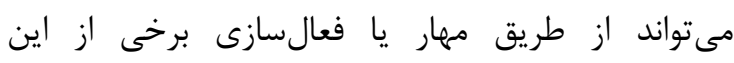

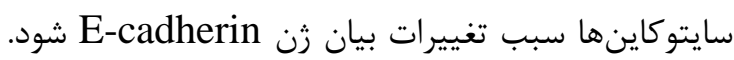


موشهاى مبتلا به سرطان يستان انجام گرفت. نتايج

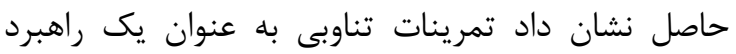
غيردارويى باعث تعديل بيان زن سركوبگر تومور، تهاجم

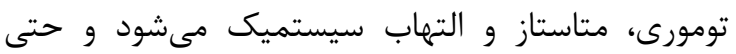
روند ييشروى بيمارى و متاستاز را معكوس مى كند. شايان ذكر است كه يزوهشهاى محدودى در زمينهى بررسى اثر برى تمرينات ورزشى و بهطور خاص تمرينات تناوبى بر بيان زن E-cadherin به عنوان يك سركوبگر تومور، حجم تومور و التهاب سيستميك يرداختهاند؛ كه اين امر تفسير نتايج در اين زمينه را دشوار مى كند. لذا يِيشنهاد مى در مطالعات آتى فاكتورها و ديخر عوامل دركير در فر درآيند متاستاز براى روشن شدن مكانيسم اثر، مورد ارزيابى قرار

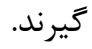

\section{تعارض منافع}

نويسندكان اعلام مىدارند كه هيج تعارض منافعى در يزوهش حاضر وجود ندارد.

\section{References}

1. Momenimovahed Z, Salehiniya H, Therapy. epidemiological characteristics of and risk factors for breast cancer in the world. Breast Cancer: Targets. 2019;11:151-64.

2. Enayatrad M, Amoori N, Salehiniya $H$. Epidemiology and trends in breast cancer mortality in iran. Iranian journal of public health. 2015; 44(3):430-1.

3. Hanahan D, Weinberg RA. Hallmarks of cancer: the next generation. Cell. 2011; 144(5):646-74.

4. Sporn MB. The war on cancer. Lancet. 1996; 347 (9012): 1377-81.

5. Cavallaro U, Christofori G. Cell adhesion and signalling by cadherins and Ig-CAMs in cancer. Nat Rev Cancer. 2004; 4(2):118-32.

6. Berx G, van Roy F. Involvement of members of the cadherin superfamily in cancer. Cold Spring Harbor perspectives in biology. 2009; 1(6): 12912.

7. Felipe Lima J, Nofech-Mozes S, Bayani J, Bartlett JM. EMT in Breast Carcinoma-A Review. J Clin Med. 2016;5(7):65-18.
قرار گيرد. اين نتايج همسو با نتايجى است كه از ديخر مطالعات در دست مىباشد (צ'، r r). رنجبر و همكاران (1) (Y)، كاهش حجم تومور را در موشهاى با سرطان ״ستان يس از شركت در يروتكل تمرينات تناوبى و و استفاده از نانوذره سلنيوم كزارش كردند (I لَ). از سوى ديگر در يزوهش حاضر وزن طحال و كبد به نسبت وزن بدن مورد بررسى قرار گرفت كه مى دواند نمايانگر غير مستقيم التهاب سيستميك باشد (اسب). نتايج يثزوش ما نشان داد كه التهاب سيستميك به طور

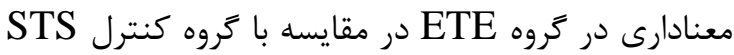

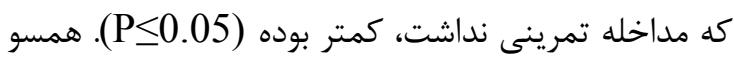
با نتايج حاضر مطالعاتى در دست مىباشد كه كاهش

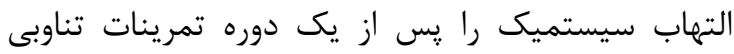

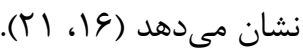

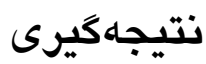

يزوهش حاضر به منظور بررسى اثر تمرينات تناوبى بر بيان

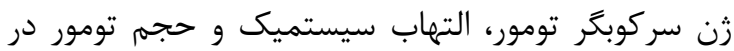

8. Katoh M. Therapeutics Targeting FGF Signaling Network in Human Diseases. Trends Pharmacol Sci. 2016; 37(12):1081-96.

9. Lee I-M. Physical activity and cancer prevention--data from epidemiologic studies. Medicine science in sports exercise. 2003;35(11):1823-7.

10. Younis LK, El Sakka H, Haque I. The Prognostic Value of E-cadherin Expression in Breast Cancer. International journal of health sciences. 2007; 1(1):43-51.

11. Rakha EA, Abd El Rehim D, Pinder SE, Lewis SA, Ellis IO. E-cadherin expression in invasive non-lobular carcinoma of the breast and its prognostic significance. Histopathology. 2005; 46(6): 685-93.

12. Liu J, Sun X, Qin S, Wang H, Du N, Li Y, Pang $\mathrm{Y}$, Wang $\mathrm{C}$, Xu C, Ren H. CDH1 promoter methylation correlates with decreased gene expression and poor prognosis in patients with breast cancer. Oncology letters. 2016;11(4): 2635-43.

13. Sadeghipour F, Gharakhanlou R, Movahedin M, Rahmati M. The effect of continues endurance training on the gene expression of GSK-3 $\beta$ in 
the sensory areas of the spinal cord of male wistar rats with diabetic neuropathy. Iranian Journal of Diabetes and Metabolism. 2015; 15(1):9-18.

14. Ruiz-Casado A, Martin-Ruiz A, Perez LM, Provencio M, Fiuza-Luces C, Lucia A. Exercise and the Hallmarks of Cancer. Trends Cancer. 2017; 3(6):423-41.

15. Ju J, Nolan B, Cheh M, Bose M, Lin Y, Wagner GC, Yang CS. Voluntary exercise inhibits intestinal tumorigenesis in $\mathrm{Apc}(\mathrm{Min} /+)$ mice and azoxymethane/dextran sulfate sodiumtreated mice. BMC cancer. 2008;8(1):316-27.

16. Gibala MJ, Little JP, MacDonald MJ, Hawley JA. Physiological adaptations to low-volume, high-intensity interval training in health and disease. The Journal of physiology. 2012; 590(5): 1077-84.

17. Meyer K, Samek L, Schwaibold M, Westbrook S, Hajric R, Lehmann M, Eßfeld D, Roskamm H. Physical responses to different modes of interval exercise in patients with chronic heart failure-application to exercise training. European heart journal. 1996; 17(7):1040-7.

18. Ashcraft KA, Peace RM, Betof AS, Dewhirst MW, Jones LW. Efficacy and Mechanisms of Aerobic Exercise on Cancer Initiation, Progression, and Metastasis: A Critical Systematic Review of In Vivo Preclinical Data. Cancer Res. 2016; 76(14):4032-50.

19. Marcinko K, Sikkema SR, Samaan MC, Kemp BE, Fullerton MD, Steinberg GR. High intensity interval training improves liver and adipose tissue insulin sensitivity. Molecular metabolism. 2015; 4(12):903-15.

20. Barra NG, Fan IY, Gillen JB, Chew M, Marcinko K, Steinberg GR, Gibala MJ, Ashkar AA. High Intensity Interval Training Increases Natural Killer Cell Number and Function in Obese Breast Cancer-challenged Mice and Obese Women. J Cancer Prev. 2017; 22(4):2606.

21. Ranjbar K, Agha Alinejad H, Shahbazi S, Molanouri Shamsi M. Interval Aerobic Exercise and Selenium Nanoparticle Stimulate Autophagy in Mice with cancer Cachexia. Int J Cancer Oncol. 2018; 5(1)35-40.

22. Faustino-Rocha A, Oliveira PA, Pinho-Oliveira J, Teixeira-Guedes C, Soares-Maia R, da Costa RG, Colaco B, Pires MJ, Colaco J, Ferreira R,
Ginja M. Estimation of rat mammary tumor volume using caliper and ultrasonography measurements. Lab Anim (NY). 2013;42(6): 217-24.

23. Massagué J. TGF $\beta$ in cancer. Cell. 2008; 134(2): 215-30.

24. Toiyama Y, Yasuda H, Saigusa S, Tanaka K, Inoue $\mathrm{Y}$, Goel A, Kusunoki M. Increased expression of Slug and Vimentin as novel predictive biomarkers for lymph node metastasis and poor prognosis in colorectal cancer. Carcinogenesis. 2013; 34(11):2548-57.

25.Zhang Q, Zhang B, Zhang K, Meng X, Jia Q, Bu Y, Zhu X, Ma D, Ye B, Zhang N. Moderate swimming suppressed the growth and metastasis of the transplanted liver cancer in mice model: with reference to nervous system. Oncogene. 2016; 35(31):4122.

26. Palena C, Hamilton DH, Fernando RI. Influence of IL-8 on the epithelial-mesenchymal transition and the tumor microenvironment. Future oncology. 2012;8(6):713-22.

27. Wendt MK, Allington TM, Schiemann WP. Mechanisms of the epithelial-mesenchymal transition by TGF- $\beta$. Future Oncology. 2009; 5(8): 1145-68.

28. Moghadddam V, Peeri M, Azarbayjani MA, Matin Homaee H. Comparison of protective effect of two types of aerobic and intermittent training on breast cancer by TGF $\beta$ protein and Smad-3 gene and MMP2 in female mice. Hormozgan Medical Journal. 2017;21(1):53-64.

29. Medeiros A, Oliveira EMd, Gianolla R, Casarini DE, Negrão C, Brum PC. Swimming training increases cardiac vagal activity and induces cardiac hypertrophy in rats. Brazilian Journal of Medical Biological Research. 2004;37(12): 1909-17.

30. Terada S, Tabata I, Higuchi M. Effect of highintensity intermittent swimming training on fatty acid oxidation enzyme activity in rat skeletal muscle. The Japanese journal of physiology. 2004;54(1):47-52.

31. Murphy EA, Davis JM, Barrilleaux T, McClellan J, Steiner J, Carmichael M, Pena MM, Hébert JR, Green J. Benefits of exercise training on breast cancer progression and inflammation in C3 (1) SV40Tag mice. Cytokine. 2011;55(2):274-9. 